\title{
HUBUNGAN PENDAPATAN, PENGETAHUAN GIZI IBU DENGAN KETERSEDIAAN IKAN TINGKAT RUMAH TANGGA DAERAH PERKOTAAN
}

\author{
S. Indriana ${ }^{(1)}$, L. Widajanti ${ }^{(2)}$
}

\begin{abstract}
Background: The role of fish as nutrients source is very important because fish contains nutrients that to be required the body. Many markets in the city that prepare daily consumption should not become barrier for serving fish dish in family menu. Moreover Semarang city is harbour city; the fish is easy to be accessed in Semarang. But until this time role of fish in consumption of traditional food is rare because apart of population less recognize the advantage of fish. The objective of this study is to analize the relationship between income, mother's nutrition knowledge and fish stock at household level. Method: This cross sectional study was conducted to 75 mothers who be educated minimal the end of high school in Jagalan house of village-head, district of Center Semarang, Semarang city, taken by systematic random sampling. Data analyzing with Spearman correlation test.

Result: Income/capita/month from mother/household ranged between Rp 99.000,00 until Rp 937.000,00. Stage of income/capita/month that more than equal with Regional Minimum Commision is 16\%, less than Regional Minimum Commision is $84 \%$. Score of mother's nutrition knowledge ranged between 50,0 until 100,0 with rate was 83,5. For category of good nutrition knowledge, the percentage is 66,7\%, enough category 30,7\% and less category 2,7\%. For fish stock in household ranged between 0-1 times/day. For category of less stock as much as 29,3\%, enough category 53,3\% and good category 17,3\%. Correlation coefficient for income/capita/month was 0,284 ( $\rho$ value 0,014). For mother's nutrition knowledge, correlation coefficient was 0,466 ( $\rho$ value 0,000). Conclusion: The higher mother's Income/capita/month and nutrition knowledge, the higher fish stock in household.
\end{abstract}

Keyword: Income, nutrition knowledge, mother, fish stock, household.

\begin{abstract}
ABSTRAK
Latar Belakang: Peranan ikan sebagai bahan penyedia gizi sangatlah penting karena ikan mengandung zat-zat gizi yang sangat dibutuhkan tubuh. Banyaknya pasar di Kota Semarang yang menyediakan kebutuhan sehari-hari, seharusnya sudah bukan merupakan halangan untuk penyajian hidangan ikan dalam тепи keluarga. Apalagi Kota Semarang merupakan kota pelabuhan, ikan mudah didapatkan. Namun sampai saat ini peran ikan dalam konsumsi pangan tradisional masih kecil karena sebagian penduduk kurang mengenal manfaat ikan. Tujuan penelitian untuk menganalisis hubungan pendapatan, pengetahuan gizi ibu dengan ketersediaan ikan di tingkat rumah tangga. Metode: Penelitian menggunakan metode penelitian survei masyarakat, jenis penelitian analitik, pendekatan waktu cross sectional. Pelaksanaan penelitian bulan September-Oktober 2004. Analisis data dengan uji korelasi Spearman. Populasi adalah ibu yang berpendidikan minimal tamat SLTA di Kelurahan Jagalan, Kecamatan Semarang Tengah, Kota Semarang (305 orang) dengan sampel sebanyak 75 orang.

Hasil: Pendapatan/kapita/bulan ibu/rumah tangga bervariasi dari Rp 99.000,00 - Rp 937.000,00. Tingkat pendapatan/kapita/bulan yang >UMR persentasenya 16\%, yang <UMR $84 \%$. Nilai pengetahuan gizi ibu tentang ikan berkisar antara 50,0-100,0 dengan nilai rata-rata 83,5. Untuk kategori pengetahuan gizi baik, persentasenya 66,7\%, kategori cukup 30,7\% dan kategori kurang 2,7\%. Untuk ketersediaan ikan tingkat rumah tangga, berkisar antara 0-1 kali/hari. Untuk kategori ketersediaan kurang ada 29,3\%, kategori cukup 53,3\% dan kategori baik 17,3\%. Hasil uji korelasi Spearman untuk pendapatan/kapita/bulan diperoleh nilai $r_{s}=0,284(p=0,014)$. Untuk pengetahuan gizi ibu tentang ikan diperoleh nilai $r_{s}=0,466$ $(p=0,000)$. Simpulan: Semakin tinggi pendapatan/kapita/bulan dan pengetahuan gizi ibu tentang ikan akan makin tinggi ketersediaan ikan di rumah tangga
\end{abstract}

Kata kunci: Pendapatan, pengetahuan gizi, ibu, ketersediaan ikan, rumah tangga

1. Alumnus Prodi S1 Ilmu Gizi, Fakultas Kedokteran, Universitas Diponegoro.

2. Bagian Gizi Kesehatan Masyarakat, Fakultas Kesehatan Masyarakat/Magister Gizi Masyarakat, Universitas Diponegoro. 


\section{PENDAHULUAN}

Ketersediaan pangan merupakan suatu kondisi penyediaan pangan yang mencakup makanan dan minuman yang berasal dari tanaman, ternak dan ikan bagi penduduk suatu wilayah dalam suatu kurun waktu tertentu, yang juga merupakan suatu sistem yang berjenjang mulai dari nasional, propinsi, lokal dan rumah tangga. Ketersediaan pangan di tingkat rumah tangga harus selalu dijaga agar keluarga tetap cukup kebutuhan pangannya, yang sekaligus akan berdampak positif terpelihara kesehatannya karena kecukupan gizi keluarga selalu terjamin. Untuk mempertahankan kesehatan, disarankan untuk memakan ikan dan makanan laut paling tidak tiga kali dalam seminggu ( 0,4 kali sehari), lebih dari 5 kali seminggu (0,7 kali sehari) adalah yang ideal. Atau minimal adalah 1 kali sehari. Peranan ikan sebagai bahan penyedia gizi sangatlah penting, karena ikan mengandung zat-zat gizi yang sangat dibutuhkan tubuh. Dengan kandungan protein yang cukup tinggi (20\%), mudah dicerna dan komposisi kandungan asam amino esensial yang seimbang, ikan juga memegang peranan penting dalam perbaikan gizi masyarakat. Ikan juga mengandung asam lemak esensial termasuk omega-3. Asam lemak esensial ini sangat diperlukan dalam pembentukan sel-sel otak untuk meningkatkan tingkat intelegensia dan pencegahan bahkan penyembuhan berbagai penyakit jantung dan "atherosclerosis". Disamping itu, hasil laut dan produk perikanan juga banyak mengandung berbagai jenis vitamin yang larut dalam lemak, khususnya vitamin $\mathrm{A}, \mathrm{D}, \mathrm{E}$ dan K. Dengan kandungan kalsium (Ca) yang tinggi, ikan dan produk perikanan juga merupakan bahan makanan yang sangat diperlukan dalam pembentukan sel-sel tulang. Ikan-ikan laut juga banyak mengandung senyawa yodium yang sangat diperlukan untuk mencegah penyakit gondok.

Pengetahuan bahan makanan perlu sebagai dasar untuk menyusun hidangan. Selain dipengaruhi besarnya pendapatan. Pendapatan dan kebiasaan makan memegang peran penting dalam konsumsi bahan makanan penduduk. Semakin tinggi taraf ekonomi seseorang, pola konsumsi terhadap bahan makanan bisa berubah (Suhardjo, 2002). Faktor yang menentukan konsumsi ikan adalah harga dan pendapatan.

Dalam kehidupan manusia pengetahuan gizi memegang peranan yang sangat penting di dalam menggunakan pangan yang baik, sehingga dapat mencapai keadaan gizi yang cukup. Pengetahuan merupakan dominan yang sangat penting untuk terbentuknya tindakan seseorang karena dari pengalaman dan penelitian ternyata perilaku yang didasari oleh pengetahuan akan lebih langgeng daripada perilaku yang tidak didasari oleh pengetahuan. Dari hasil penelitian tentang hubungan tingkat pendidikan ibu dan pengetahuan gizi tentang ASI dengan lama pemberian ASI di desa Pringtulis Kecamatan Nalumsari Kabupaten Jepara (2003), diketahui bahwa ibu dengan pendidikan >SLTA mempunyai pengetahuan gizi yang baik.

Kelurahan Jagalan merupakan salah satu kelurahan yang ada di kota Semarang. Banyaknya pasar di Kota Semarang yang menyediakan kebutuhan sehari-hari, seharusnya sudah bukan merupakan halangan dalam penyajian hidangan ikan dalam menu keluarga. Apalagi bagi Kota Semarang yang merupakan kota pelabuhan, ikan mudah didapatkan. Namun demikian sampai saat ini peran ikan dalam konsumsi pangan tradisional masih kecil. Ikan kalah bersaing dengan produk unggas dan ternak (ayam, kambing, sapi dan produk sampingnya seperti telur dan susu). Dari data SUSENAS BPS Tahun 19961999 diketahui bahwa konsumsi ikan masih rendah. Hingga Tahun 2002 konsumsi ikan di Kota Semarang masih terus menurun. Masih rendahnya masyarakat yang mengkonsumsi ikan antara lain karena kurangnya pemahaman akan manfaat mengkonsumsi ikan, kurangnya daya beli ikan dan masih mahalnya harga ikan bagi sebagian masyarakat yang mengkonsumsi ikan. Tujuan penelitian adalah untuk menganalisis hubungan pendapatan/kapita /bulan dan pengetahuan gizi ibu tentang ikan dengan ketersediaan ikan di tingkat rumah tangga daerah perkotaan. 


\section{METODE}

Penelitian dilakukan di Kelurahan Jagalan, Kecamatan Semarang Tengah, Kota Semarang, dilakukan pada bulan September Oktober Tahun 2004. Penelitian ini merupakan penelitian gizi masyarakat. Penelitian ini menggunakan metode penelitian survei masyarakat dengan pendekatan waktu cross sectional. Jenis penelitian adalah penelitian analitik.

Populasi target adalah semua ibu di Kelurahan Jagalan, Kecamatan Semarang Tengah, Kota Semarang (1628 orang). Populasi terjangkau meliputi ibu yang berpendidikan minimal tamat SLTA di Kelurahan Jagalan, Kecamatan Semarang Tengah, Kota Semarang (305 orang). Hal ini berdasarkan penelitian tentang hubungan antara tingkat pendidikan ibu batita dan pengetahuan gizi tentang ASI dengan lama pemberian ASI di desa Pringtulis Kecamatan Nalumsari Kabupaten Jepara (2003), diketahui bahwa ibu dengan pendidikan yang tinggi (>SLTA) mempunyai pengetahuan tentang gizi yang baik pula.

Besar sampel minimal pada penelitian ini adalah 75 orang. Pengambilan sampel menggunakan metode Systematic Random Sampling (pengambilan sampel dengan Acak Sistematik) dengan kriteria ibu yang bertempat tinggal di Kelurahan Jagalan, Kecamatan Semarang Tengah, Kota Semarang dan berpendidikan minimal tamat SLTA.

Variabel bebas terdiri atas pendapatan/kapita /bulan dan pengetahuan gizi ibu tentang ikan. Sedangkan variabel terikatnya adalah ketersediaan ikan ditingkat rumah tangga. Pendapatan/kapita/bulan didefinisikan sebagai jumlah pendapatan rumah tangga yang dihitung berdasarkan pengeluaran rumah tangga (pangan maupun non pangan) dibagi dengan jumlah anggota rumah tangga dalam satu rumah dan dinyatakan dalam rupiah perkapita perbulan. Pendapatan/kapita/bulan dikategorikan menjadi dua kategori, yaitu $<$ UMR dan > UMR. Upah Minimum Regional untuk Kota Semarang Tahun 2004 adalah Rp $450.000,00$ per orang (Bank Indonesia, 2004).
Rumah tangga didefinisikan sebagai seseorang/sekelompok orang yang mendiami sebagian/seluruh bangunan fisik/sensus dan makan bersama dan satu dapur (pengurusan kebutuhan sehari-hari dikelola menjadi satu).

Pengetahuan gizi ibu tentang ikan didefinisikan sebagai pengetahuan ibu tentang guna makanan dan ikan, jenis pilihan sumber protein hewani, cara memilih ikan yang baik, kandungan gizi pada ikan, yang disusun dalam 20 pertanyaan. Soal dengan jawaban benar diberi nilai 5. Sedangkan jawaban yang salah diberi nilai 0 . Nilai tertinggi yang dapat diperoleh adalah 100. Nilai dikategorikan menjadi 3 kategori, yaitu ketegori pengetahuan gizi baik jika $>80 \%$ jawaban benar, kategori cukup jika $60-80 \%$ jawaban benar dan kategori kurang jika $<60 \%$ jawaban benar (Baliwati et al., 2004).

Ketersediaan ikan di tingkat rumah tangga didefinisikan sebagai frekuensi dan tempat pembelian ikan sebagai menu rumah tangga dalam setiap hari. Ketersediaan ikan di tingkat rumah tangga dikategorikan menjadi 3 kategori, yaitu kategori baik jika ketersediaan ikan di tingkat rumah tangga $>0,7 \mathrm{x} / \mathrm{hari}$ (>5x/minggu), kategori cukup jika 0,4$0,6 \mathrm{x} /$ hari (3-4x/minggu) dan kategori kurang jika $<0,3 \mathrm{x} /$ hari $(0-2 \mathrm{x} / \mathrm{minggu})$ (Departemen Kelautan dan Perikanan, 2004).

Instrumen yang digunakan dalam penelitian ini adalah berupa kuesioner terstruktur yang disusun menurut variabel yang akan diteliti. Analisis data dilakukan dengan menggunakan program pengolah data. Untuk melakukan pengolahan data menggunakan uji Spearman. Probabilitas dianggap bermakna secara statistik apabila didapatkan nilai $\rho<0,05$.

\section{HASIL PENELITIAN}

\section{Pendidikan Ibu}

Dari 75 orang, sebagian besar berpendidikan tamat SLTA (77,3\%). Untuk penyebaran ibu menurut pendidikan dapat dilihat pada gambar 1 . 


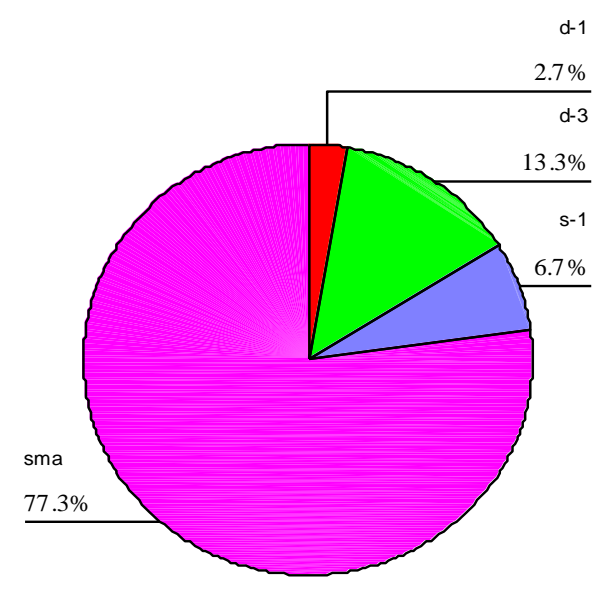

Gambar 1. Penyebaran ibu menurut jenis pendidikan

\section{Status Pekerjaan Ibu}

Dari hasil penelitian diketahui bahwa sebagian besar ibu berstatus sebagai ibu rumah tangga, yaitu sebanyak 58,7\% (Gambar 2).

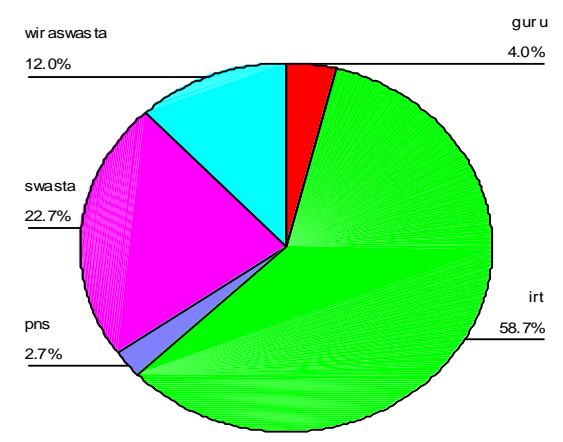

Gambar 2. Penyebaran ibu menurut status pekerjaan

\section{Ketersediaan Ikan di Tingkat Rumah Tangga}

Dari hasil penelitian diketahui bahwa yang tidak pernah menyediakan ikan sebagai menu keluarga dalam sehari ada 1,3\%. Sedangkan yang ketersediaan ikannya 1 kali sehari ada $2,7 \%$. Ketersediaan disini adalah ketersediaan ikan di dalam rumah tangga yang dilakukan oleh rumah tangga sendiri. Untuk kategori ketersediaan ikan di tingkat rumah tangga sebagian besar termasuk kategori cukup, yaitu sebanyak 53,3\% (Gambar 3).

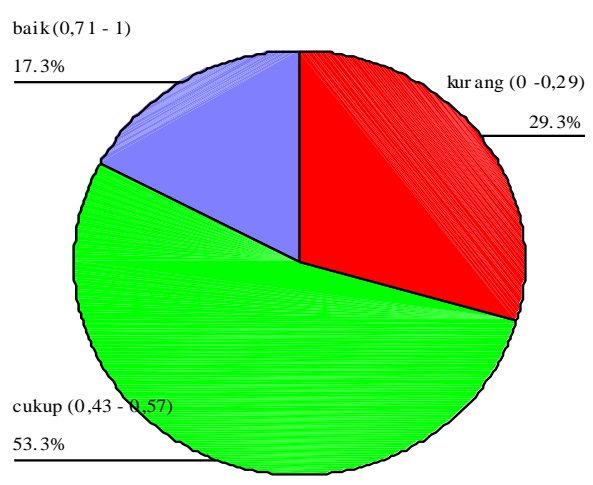

Gambar 3. Penyebaran ibu menurut kategori ketersediaan ikan di tingkat rumah tangga

\section{Pendapatan/kapita/bulan}

Pendapatan/kapita/bulan dari ibu/rumah tangga bervariasi dari Rp 99.000,00 sampai Rp 937.000,00. Dari hasil penelitian diketahui bahwa tingkat pendapatan/kapita/bulan yang lebih besar sama dengan UMR (Upah Minimum Regional) untuk kota Semarang, persentasenya adalah sebesar $16 \%$. Sedangkan yang kurang dari UMR adalah $84 \%$ (Gambar 4).

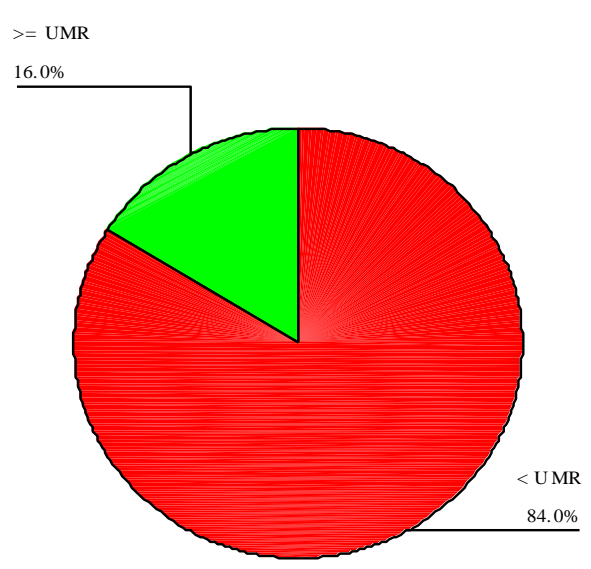

Gambar 4. Penyebaran ibu menurut kategori pendapatan/kapita/bulan 


\section{Pengetahuan Gizi Ibu Tentang Ikan}

Dari hasil penelitian diketahui bahwa nilai pengetahuan gizi ibu tentang ikan berkisar antara 50 sampai 100 dengan rata-rata 83,5. Sebagian besar pengetahuan gizi ibu tentang ikan termasuk kategori baik, yaitu sebanyak $66,7 \%$ (Gambar 5).

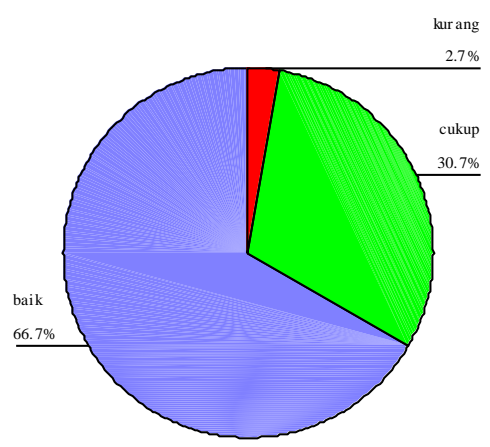

Gambar 5. Penyebaran ibu menurut kategori pengetahuan gizi ibu tentang ikan

Dari hasil pengolahan data didapatkan nilai minimum, nilai maksimum, nilai rata-rata dan standar deviasi (Tabel 1)

Setelah dilakukan uji Kolmogorov Smirnov (uji normalitas distribusi data), diketahui bahwa data berdistribusi tidak normal. Sehingga uji statistik yang digunakan adalah uji korelasi Spearman.

\section{Hubungan Pendapatan/kapita/bulan dengan Ketersediaan Ikan di Tingkat Rumah Tangga Daerah Perkotaan}

Dari analisis data dengan menggunakan uji Spearman didapatkan nilai koefisien korelasi $\left(r_{\mathrm{s}}\right)$ sebesar 0,284 dengan taraf signifikansi ( $\rho$ value) $0,014 \quad(<0,05)$. Jadi ada hubungan pendapatan/kapita/bulan dengan ketersediaan ikan di tingkat rumah tangga daerah perkotaan.

\section{Hubungan Pengetahuan Gizi Ibu tentang Ikan dengan Ketersediaan Ikan di Tingkat Rumah Tangga Daerah Perkotaan.}

Dari hasil uji korelasi Spearman antara pengetahuan gizi ibu tentang ikan dengan ketersediaan ikan di tingkat rumah tangga didapat nilai koefisien korelasi $\left(\mathrm{r}_{\mathrm{s}}\right)$ sebesar 0,466 dan nilai $\rho$ value $0,000(<0,05)$, yang berarti terdapat hubungan pengetahuan gizi ibu tentang ikan dengan ketersediaan ikan di tingkat rumah tangga daerah perkotaan.

\section{PEMBAHASAN}

Ketersediaan makanan di rumah tangga dipengaruhi oleh beberapa faktor antara lain daya beli, jumlah anggota keluarga, sosial budaya, harga bahan makanan, pendidikan dan pengetahuan gizi. Untuk mewujudkan ketahanan pangan rumah tangga perlu memperhatikan faktor ketersediaan pangan, daya beli dan pengetahuan gizi. Dan untuk memperbaiki kualitas ketersediaan pangan harus diikuti oleh upaya-upaya peningkatan pendapatan serta peningkatan pengetahuan dan kesadaran gizi masyarakat. Oleh karena itu dalam penelitian ini variabel yang akan diteliti meliputi variabel pendapatan /kapita/bulan, pengetahuan gizi ibu tentang ikan dan ketersediaan ikan di tingkat rumah tangga daerah perkotaan.

\section{Hubungan Pendapatan/kapita/bulan dengan Ketersediaan ikan di Tingkat Rumah Tangga Daerah Perkotaan}

Dari hasil penelitian diketahui bahwa antara pendapatan/kapita/bulan dengan ketersediaan ikan di tingkat rumah tangga terdapat hubungan yang signifikan. Hal ini disebabkan karena harga ikan relatif lebih murah dibandingkan bahan makanan sumber protein hewani lainnya seperti daging sapi, ayam dan telur. Sehingga mudah terjangkau oleh seluruh lapisan masyarakat. Mengacu pada nilai koefisien korelasi $\left(r_{s}\right)$ yang positif $(0,284)$, hal ini mengandung arti bahwa setiap peningkatan yang terjadi pada pendapatan/kapita/bulan maka meningkat pula ketersediaan ikan di tingkat rumah tangga. Hal ini sesuai dengan teori yang mengatakan bahwa peningkatan pendapatan mempengaruhi pengadaan bahan makanan. Jika faktor pendapatan meningkat, pola penyediaan bahan makanan di rumah dapat berubah. Masyarakat yang mempunyai pendapatan cukup akan mengkonsumsi bahan 
makanan yang mempunyai nilai sosial dan nilai gizi yang lebih baik.

Tabel 1. Ringkasan statistik

\begin{tabular}{lcccc}
\hline & Minimum & Maksimum & Rata-rata & Standar Deviasi \\
\hline Pendapatan/kapita/bulan & 99 & 937 & 288.92 & 175.72 \\
$\begin{array}{l}\text { Skor pengetahuan gizi ibu } \\
\text { tentang ikan }\end{array}$ & 50 & 100 & 83.47 & 11.09 \\
$\begin{array}{l}\text { Ketersediaan ikan/hari } \\
\text { (kali) di tingkat rumah } \\
\text { tangga }\end{array}$ & 00 & 1.00 & 4419 & 1867 \\
\hline
\end{tabular}

\section{Hubungan Pengetahuan Gizi Ibu Tentang Ikan dengan Ketersediaan Ikan di Tingkat Rumah Tangga Daerah Perkotaan}

Dari hasil uji korelasi antara pengetahuan gizi ibu tentang ikan dengan ketersediaan ikan di tingkat rumah tangga diketahui terdapat hubungan yang sangat signifikan antara keduanya. Hasil ini sesuai dengan penelitian tentang hubungan tingkat pengetahuan ibu tentang manfaat ikan dengan konsumsi ikan keluarga di kompleks perumahan Kekancan Mukti (Ganesha) Kodya Semarang yang diperoleh hasil terdapat hubungan antara kedua variabel tersebut. Dan hal ini juga sejalan dengan keadaan di Daerah Istimewa Yogyakarta bahwa konsumsi ikan per orang atau masyarakat Daerah Istimewa Yogyakarta cenderung meningkat dari tahun ke tahun karena adanya penyuluhan tentang manfaat ikan yang dilakukan oleh petugas Bina Mutu Dinas Perikanan Daerah Istimewa Yogyakarta.

Semakin tinggi pengetahuan gizi seseorang akan semakin memperhitungkan jenis dan jumlah makanan yang dipilih untuk dikonsumsi. Orang yang pengetahuan gizinya rendah akan berperilaku memilih makanan yang menarik panca indera dan tidak mengadakan pilihan berdasarkan nilai gizi makanan. Sebaliknya mereka yang semakin tinggi pengetahuan gizinya lebih banyak mempergunakan pertimbangan rasio dan pengetahuan tentang nilai gizi makanan tersebut (Sediaoetama, 1993).

Pengetahuan seseorang biasanya diperoleh dari pengalaman yang berasal dari berbagai macam sumber, misalnya media massa, media elektronik, buku petunjuk dan kerabat dekat. Pengetahuan ini dapat membentuk keyakinan tertentu sehingga seseorang berperilaku sesuai kenyataan tersebut.

\section{SIMPULAN DAN SARAN}

\section{SIMPULAN}

Dan hasil penelitian dapat disimpulkan bahwa jika pendapatan/kapita/bulan dari ibu/rumah tangga tinggi, ketersediaan ikan di rumah tangga juga tinggi. Demikian pula dengan pengetahuan gizi ibu. Semakin tinggi pengetahuan gizi ibu tentang ikan akan makin tinggi ketersediaan ikan di tingkat rumah tangga.

\section{SARAN}

Bagi ibu-ibu, sebagai penentu dan pengelola makanan di rumah, dianjurkan untuk dapat 
menyediakan ikan dalam menu keluarga setidaknya $3 \mathrm{x}$ seminggu, $>5 \mathrm{x}$ seminggu idealnya, atau minimal $1 \mathrm{x} / \mathrm{hari}$, mengingat pentingnya peranan ikan sebagai bahan penyedia gizi dan kelebihan ikan dibanding sumber protein hewani lainnya, terutama ikan yang banyak mengandung asam lemak omega-3, seperti ikan kembung, ikan tongkol, ikan tengiri dan lain-lain.

Penelitian ini hendaknya dapat dikembangkan dengan penelitian yang bertujuan untuk mengetahui perbedaan antara ketersediaan ikan di daerah nelayan dan daerah bukan nelayan serta faktor-faktor yang mempengaruhi ketersediaan ikan di tingkat rumah tangga.

\section{DAFTAR PUSTAKA}

Baliwati YF, Komshan A \& Dwiariani CM 2004. Pengantar Pangan dan Gizi. Jakarta: Penebar Swadaya.

Bank Indonesia 2004. Kajian Ekonomi Regional Propinsi Jawa Tengah Triwulan I Tahun 2004. Semarang.

Departemen Kelautan dan Perikanan 2004. Gerakan Makan Ikan Sumber Protein Hewani. Jakarta: Direktorat Jenderal Perikanan Budidaya.

Sediaoetama 1993. Ilmu Gizi Untuk Mahasiswa dan Profesi Indonesia. Jakarta: Dian Rakyat.

Suhardjo 2002. Berbagai Cara Pendidikan Gizi. Jakarta: Bumi Aksara. 